\title{
RELATIONSHIP BETWEEN PHARMACOLOGICAL ACTIONS ON THE MAMMALIAN ILEUM AND CHEMICAL STRUCTURE OF $r$-AMINOBUTYRIC ACID
}

\author{
Hidehiko Takahashi, Keiko Uchikura, Hisashi Takahashi \\ AND Osamu IKEDA* \\ Department of Physiology, Tokyo Medical College, Higashiokubo \\ Shinjuku-ku, Tokyo
}

The authors have been interested in the relation between the biological actions and chemical structure of $\gamma$-aminobutyric acid (GABA). In the present investigation, we have treated the actions of various derivatives of GABA on the isolated mammalian ileum.

\section{METHODS}

Isolated ileum preparations were obtained from guinea pigs, rabbits and cats. These isolated organs were suspended in Tyrode solution bath, whose volume was kept constant at $60 \mathrm{ml}$. Tyrode solution was aerated with oxygen. The temperature at which the experiments were carried out was $37^{\circ} \mathrm{C}$. Changes in tones exerted in the longitudinal direction and the radial direction were separately recorded by Јов and others' method ${ }^{1)}$ on a smoked drum by means of isotonic writing lever (amplification about 6-fold). Unless otherwise stated drugs were allowed to act for $30 \mathrm{sec}$.1 min. while a maximum effect had developed. The organ bath was then drained and refilled with fresh, pre-warmed and oxygenated Tyrode solution; the change of Tyrode solution was repeated $1 \mathrm{~mm}$. later.

All the test substances had been synthetized for these experiments. The authors are thankful for the cooperation of the Daiichi Seiyaku Institute. The esters of GABA were used as $\mathrm{HCl}$ salts, $\mathrm{N}$-trimethyl derivatives of GABA as iodide or chloride and methyl isonicotinate as phosphate.

Throughout the text, final concentrations in the organ bath are given in preference to quantities added. For simplicity these substances are referred to by the name of the base only, but all concentrations given refer to the salts. For derivatives of GABA, the abbreviations, such as GABA-methylester for $\gamma$-aminobutyryl-methylester, were used.

\section{RESULTS}

GUINEA-PIG ILEUM

Effects of GABA and other w-amino-acids The reactions of guinea-pig ileums

Received for publication November 1, 1960.

* 高橋日出彦, 内倉敬子, 高橋長, 池田修 
to GABA were different from preparations to preparations, but they were summarized in three principal types: (I) sustained increase in tone, (II) relaxation or (III) transient increase in tone followed by subsequent relaxation (FIG. 1, A, $B, C)$. Although the reaction of preparations to GABA was different from each other, it was considerably constant in a preparation and a preparation showed repeatedly one and the same type of reaction to GABA. About the reaction of guinea-pig ileum to GABA, HoBBIGER ${ }^{2)}$ had reported in details. Our observations accorded essentially to his results.

FIG. 1. Effects of GABA and its N-substitutes on a guinea-pig ileum. G-GABA, MG-N-methyl-GABA, D-G-N-dimethyl-GABA, T-G-N-trimethyl-GABA. In all the cases, except A, e (in this case $20 \mu \mathrm{g} / \mathrm{ml}$ GABA was applied), drugs of $10 \mu \mathrm{g} / \mathrm{ml}$ were given. A-type I effect of GABA B-type II effect, C-type III effect.

In this and all the following figures, the upper tracing is movements of the circular muscle, and the lower tracing movements of the longitudinal muscle. Time marks represent $24 \mathrm{sec}$. intervals.

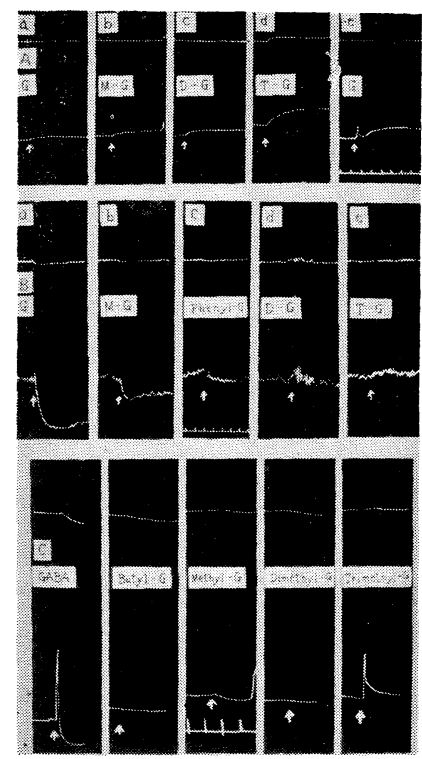

Among $\omega$-amino-acid, such as glycine, $\beta$-alanine, $\delta$-aminovaleric acid and $\varepsilon$-aminocaproic acid, only $\beta$-alanine produced sometimes a very slight relaxation at higher concentration $\left(10^{-2} \mathrm{M} / 1\right)$ and others had no effect. Further, $\beta$-aminoisobutyric acid and $\alpha$-amino-n-butyric acid had not any effect in the concentration of $10^{-2} \mathrm{M} / 1$.

Effects of nicotinic acid, isonicotinic acid and their methylesters Our attention has been directed to the action of nicotinic acid and isonicotinic acid, because the distance between $\mathrm{N}$-atom and carboxylic group in these acids is similar to that in GABA. These acids $\left(10^{-3} \mathrm{M} / 1\right)$ relaxed slightly the ileum, but they had not any stimulant effect. Methylesters of these acids produced likewise a slight relaxation.

Effects of 4-aminobutanol, $N$-methyl-4-aminobutanol and n-butyric acid The effects of 4-aminobutanol and N-methyl-4-aminobutanol were very weak. 4aminobutanol at $3 \times 10^{-2} \mathrm{M} / 1$ and $\mathrm{N}$-methyl-4-aminobutanol at $10^{-2} \mathrm{M} / 1$ produced a slight increase in tone. On the other hand, n-butyric acid had no effect. 
Effects of $N$-substituents of GABA In preparations where GABA produced the type (I) reaction, the stimulant effects of $\mathrm{N}$-methyl-substituents were in the order of $\mathrm{GABA}<\mathrm{N}$-methyl-GABA $<\mathrm{N}$-dimethyl-GABA $<\mathrm{N}$-trimethyl-GABA. However, in preparations which responded to GABA with the type (II) reaction, their relaxing effects were in the order of GABA $>\mathrm{N}$-methyl-GABA $>\mathrm{N}$-dimethylGABA $>\mathrm{N}$-trimethyl-GABA. In preparations where GABA had the type (III) of effect, the order of the activities of these substances was sometimes obscure, but in most cases the effect of GABA was most powerful (FIG. 1, A, B, C). On the other hand, N-butyl-GABA and N-phenyl-GABA were less effective than $\mathrm{N}$-methyl-GABA. Acetylation of GABA (N-acetyl-GABA) reduced also the effect of GABA remarkably.

Effects of methylesters of GABA GABA-methylester had always a stimulant effect, and it produced a powerful and sustained increase in tone even in preparations where GABA caused an evident relaxation. The stimulant effect of GABAmethylester was hardly changed by N-monomethylation (FIG. 2), although the effect of the latter was sometimes more pronounced than that of the former.
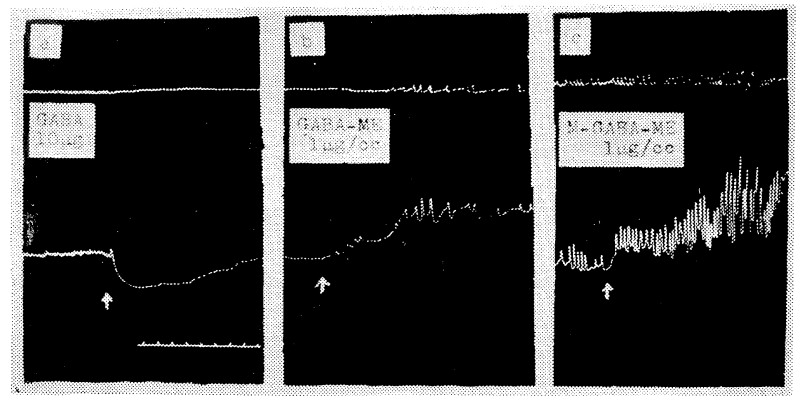

FIG. 2. Effects of GABA $(10 \mu \mathrm{g} / \mathrm{ml})$, GABA-methylester $(1 \mu \mathrm{g} / \mathrm{ml})$ and $\mathrm{N}$-methyl-GABA-methylester $(1 \mu \mathrm{g} / \mathrm{ml})$ on a guinea-pig ileum.

However, the stimulant effect of N-dimethyl-GABA-methylester was much more powerful than that of N-methyl-GABA-methylester and the stimulant effect of methylesters of GABA reached the maximum in N-trimethyl-GABA-methylester. None the less, the effect of N-trimethyl-GABA-methylester was far inferior to that of acetylcholine-chloride, the latter being more than 100 -fold powerful as the former. In FIG. 3 a typical example of the effects of methylesters of GABA is set forth.

The stimulant effect of methylesters of GABA was antagonized by $0.1 \mu \mathrm{g} / \mathrm{ml}$ atropine sulphate (FIG. 4). It had been reported by HoBBIGER ${ }^{2)}$ that the effect of GABA was antagonized by $0.1 \mu \mathrm{g} / \mathrm{ml}$ atropine sulfate. We did not try to analyze in detail the antagonism between methylesters of GABA and atropine.

The effects of GABA-methylester, N-methyl-GABA-methylester, N-ethylGABA-methylester and N-butyl-GABA-methylester were compared in one and the same preparations. Among these esters, N-methyl-GABA-methylester had 

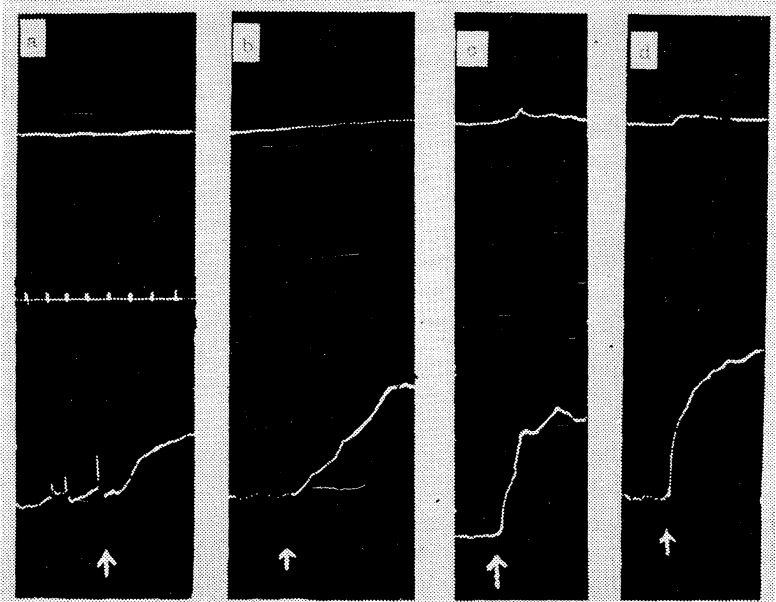

Fig. 3. Effects of methylesters of GABA and Ach. on a guinea-pig ileum. a, N-methyl-GABA-methylester $(1 \mu \mathrm{g} / \mathrm{ml}), \quad \mathrm{b}$, N-dimethyl-GABAmethylester $(0.25 \mu \mathrm{g} / \mathrm{ml}), \mathrm{c}$, N-trimethyl-GABA-methylester $(0.025 \mu \mathrm{g} / \mathrm{ml})$ and $\mathrm{d}$, Ach $(0.0002 \mu \mathrm{g} / \mathrm{ml})$.

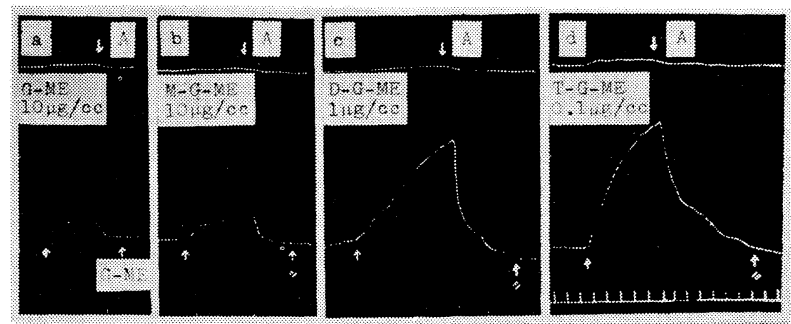

FIG. 4. Antagonism between GABA-methylesters and atropine. G-ME indicates GABA-methylester, M-G-ME-N-methyl-GABA-methylester, D-G$\mathrm{ME}-\mathrm{N}$-dimethyl-GABA-methylester and T-G-ME-N-trimethyl-GABAmethylester. A represents atropine sulfate. At first a test substance was introduced into organ bath, and after the maximal effect had developed, atropine was given. Atropine completely antagonized to GABA-methylesters. Thereafter, a test substance was again brought in organ bath. Then, organ bath was drained. In this experiment, $20 \mu \mathrm{g} / \mathrm{ml}$ atropine sulfate was used, but in other experiments $0.1 \mu \mathrm{g} / \mathrm{ml}$ atropine produced similar antagonistic effect.

the strongest stimulant effect. The stimulant effect of GABA-methylester was weakened by $\mathrm{N}$-butylation or by $\mathrm{N}$-ethylation, but not by $\mathrm{N}$-methylation. And $\mathrm{N}$-phenylation reversed the effect of GABA-methylester to a relaxing one.

Effects of esters of $N$-methyl-GABA Although N-methyl-GABA-methylester had a stimulant action, $\mathrm{N}$-methyl-GABA-ethylester produced a slight relaxation in lower concentrations. However, in higher concentrations it had a tone-increasing action, though it was weaker than that of N-methyl-GABA-methylester (FIG. 5). 

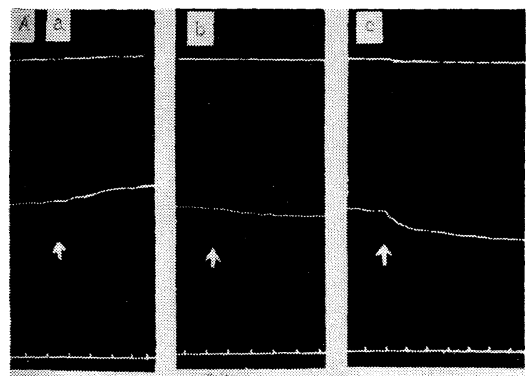

FIG. 5. Effects of N-methyl-GABAmethylester (a), N-methyl-GABA-ethylester (b) and N-methyl-GABA-butylester (c), on a guinea-pig ileum. In $\mathrm{A}$, the concentrations of drugs were $1 \mu \mathrm{g} / \mathrm{ml}$, in B $5 \mu \mathrm{g} / \mathrm{ml}$.
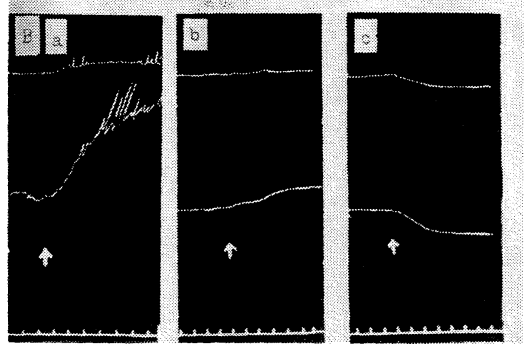

$\mathrm{N}$-methyl-GABA-butylester and N-methyl-GABA-benzylester produced a relaxation in higher concentrations than $10^{-5}$ mole $/ 1$.

The effects of N-phenyl-GABA-methylester, N-methyl-GABA-butylester and $\mathrm{N}$-methyl-GABA-benzylester were compared in one and the same preparation. The relaxing effects of N-methyl-GABA-butylester and N-methyl-GABA-benzylester were more powerful than that of N-phenyl-GABA-methylester. On the other hand, the effects of both esters were of almost the same degree, but the effect of N-methyl-GABA-butylester was slightly stronger than that of N-methylGABA-benzylester (FIG. 6).

Subsequently, the effect of low N-methyl-GABA-butylester was observed in some detail. Astonishing to us, $10^{-\tau}$ mole/1 N-methyl-GABA-butylester had sometimes a slight but apparent stimulant effect on the guinea-pig ileum. Its stimulant action was decreased with increase in the concentration $\left(10^{-7}-10^{-5} \mathrm{~mole} / 1\right)$ and reversed to relaxing one in higher concentration than $10^{-5} \mathrm{~mole} / 1$.

Effects of $\gamma$-amino- $\beta$-hydroxy-butyric acid and its methylester $\gamma$-Amino- $\beta$ hydroxy-butyric acid (GABOB, Ono Seiyaku Co.) had a similar action to that of GABA. When GABA or GABOB was applied repeatedly at short intervals, adaptation occurred apparently in the ileum preparation, as was reported by HobBIGER ${ }^{2)}$. Such adaptation was likewise seen obviously, if GABA and GABOB were repeatedly applied one after the other (FIG. 7).

According to $\mathrm{HOBBIGER}^{2)}$, the activity of GABOB was approximately onequarter of that of GABA. Although we did not compare the activity of these acids with each other, the activity of the methylesters of two acids was compared in the same preparations. The effect of GABA-methylester was doubtlessly more pronounced than that of GABOB-methylester. The latter had no effect at the 

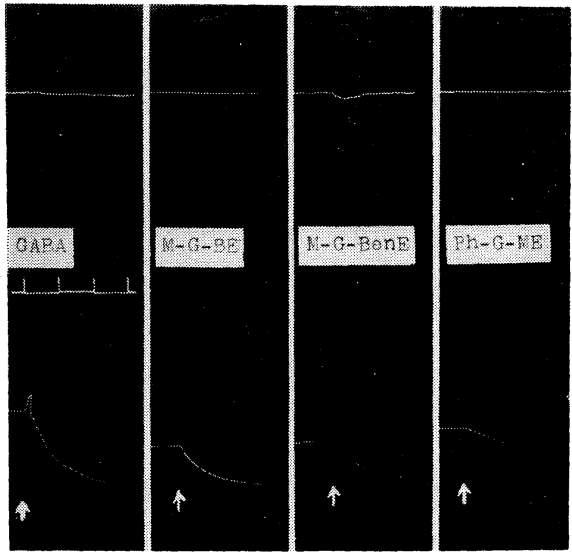

FIG. 6. Effects of GABA, N-methylGABA-butylester, N-methyl-GABA-benzylester and N-phenyl-GABA-methylester on a guinea-pigileum. They were applied in $10^{-4}$ $\mathrm{M} / 1$ concentration.
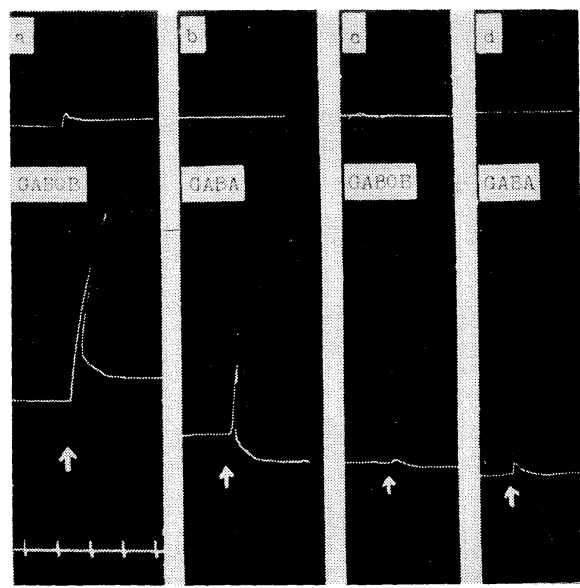

FIG. 7. Adaptation of a guinea-pig ileum to GABA and $\gamma$-amino- $\beta$-hydroxy-butyric acid (GABOB), applied one after the other. Their concentrations used were $10^{-3} \mathrm{M} / 1$. Each experiment was done after draining and refilling of organ bath. It took 1-2 min. to do these operations.

TABLE 1.

\begin{tabular}{|c|c|}
\hline Substances (order of activities) & Effect \\
\hline $\begin{array}{l}\text { Glycine, } \beta \text {-Alanine, } \delta \text {-Aminovaleric acid, } \\
\varepsilon \text {-Aminocaproic acid, } \alpha \text {-Amino-n-butyric } \\
\text { acid, } \beta \text {-Aminoisobutyric acid }\end{array}$ & None \\
\hline $\begin{array}{l}\text { GABA }>\text { N-methyl-GABA }>\text { N-phenyl-GABA, } \\
\text { N-acetyl-GABA }>\text { N-dimethyl-GABA }> \\
\text { N-trimethyl-GABA: } \\
\text { N-methyl-GABA-butylester, N-methyl-GABA- } \\
\text { benzylester }>\text { N-phenyl-GABA-methylester: } \\
\text { Nicotinic acid, Isonicotinic acid, } \\
\text { Methyl nicotinate, Methyl isonicotinate }\end{array}$ & Relaxation \\
\hline $\begin{array}{l}\text { N-trimethyl-GABA-methylester }>\text { N-dimethyl- } \\
\text { GABA-methylester }>\text { N-methyl-GABA-methylester, } \\
\text { GABA-methylester }>\text { N-methyl-GABA-ethylester }> \\
\text { N-trimethyl-GABA }>\text { N-dimethyl-GABA }>\text { N-methyl- } \\
\text { GABA }>\text { GABA }>N \text {-phenyl-GABA, N-acetyl-GABA: } \\
\text { GABA }>\text { N-methyl-4-aminobutanol }>4 \text {-aminobutanol }\end{array}$ & Increase in tone \\
\hline
\end{tabular}

concentration of $10^{-3}$ mole $/ 1$. Our findings show also evidence that $\mathrm{OH}$-group at $\beta$-position reduces the biological action of GABA on the ileum.

In TABLE 1, the experimental results obtained about the effects of derivatives of GABA on the guinea-pig ileum are summarized. 


\section{RABBIT ILEUM}

The effects of GABA, GABOB and N-methyl derivatives of GABA on the tone of rabbit ileums were essentially the same as on that of the guinea-pig ileum, although they were all weaker on the former than on the latter. In rabbit ileums, the effects of test substances on spontaneous activity (pendel movement) were also observed. The drugs which relaxed the ileum, such as N-methyl-GABAbutylester and so on, reduced the amplitude and frequency of spontaneous activity.

\section{CAT ILEUM}

On the cat ileum, all the test substances had the similar effects to those on the guinea-pig ileum and on the rabbit ileum. The activities of the test substances in the cat ileum were quantitatively of the same degrees as in the guinea-pig ileum.

\section{DISCUSSION}

The effect of GABA on the ileum was investigated in some details by HobBIGER $^{2,3}$ and INOUYE et al.4) They have found that GABA has a dualtone-increasing and relaxing-action on the ileum. Our observations accorded with those of them.

It has been acknowledged by many investigators ${ }^{5-8}$ ) that in the biological action of GABA, the distance between the amino-group and the carboxylic group has an essential importance. We believe that in the present investigation we could demonstrate the following facts: (1) In the effect of GABA on the ileum, both amino-group and carboxylic group are indispensable; (2) The distance between the amino-group and the carboxylic group is an essential determining factor of its activity; (3) N-substitution by any groups and methylesterification reduce the inhibitory or relaxing action of GABA. On the contrary, Methylesterification strengthens its stimulant effect.

Our finding that the stimulant action of GABA became stronger, as the chemical structure became more similar to that of acetylcholine, suggests that GABA may react upon Ach-receptor. The interpretation that the inhibitory action of GABA may be due to some competition with Ach for the same receptor could be true within some limits, for the stimulant activity of GABA is very low in comparison with that of Ach. However, such interpretation seems to be too simple, for GABA itself may change the excitability of neuronal elements in the ileum. Besides, INOUYE et $\mathrm{al}^{4)}$ have insisted that GABA seems to interact more effectively with the receptor which is reactive to 5-hydroxytryptamine.

In the stimulant effect of GABA, not only carbonyl group, but also hydroxygroup may have some significance, although the latter group is likely to be less important than the former, 
SUMMARY

The effects of GABA, its derivatives and their related compounds on the isolated ileum of the guinea-pig, rabbit and cat were investigated.

1. GABA had three types of effect on the guinea-pig ileum under various conditions; i.e. sustained tone-increasing, or relaxing or transient tone-increasing one followed by relaxation.

2. Other $\omega$-amino-acids, such as glycine, $\delta$-aminovaleric acid and $\varepsilon$-aminocaproic acid had no effect. Only $\beta$-alanine at $10^{-2} \mathrm{M} / 1$ produced sometimes only a slight relaxation. $\alpha$-amino-n-butyric acid and $\beta$-amino-isobutyric acid had no effect.

3. 4-Aminobutanol and N-methyl-4-aminobutanol at very high concentrations had a slight stimulant action, although n-butyric acid had no effect.

4. N-Substitution with acetyl, phenyl, butyl or methyl group reduced relaxing activity of GABA.

5. Methylesterification of GABA strengthened its stimulant activity. The stimulant effects of methylesters were antagonized by atropine.

6. As the chemical structure of GABA became more similar to that of Ach, its stimulant activity became progressively higher. However, even N-trimethylGABA-methylester, whose effect was strongest among the methylesters, was by far weaker than Ach.

7. N-Ethylation and N-butylation weakened the stimulant effect of GABAmethylester and $\mathrm{N}$-phenylation reversed it into a relaxing one.

8. N-Methyl-GABA-ethylester had a weaker stimulant effect than N-methylGABA-methylester, and N-methyl-GABA-butylester and N-methyl-GABA-benzylester had a marked relaxing effect.

9. N-Methyl-GABA-ethylester had a weak relaxing action in lower concentrations, but a stimulant effect in higher concentrations. On the contrary, N-methylbutylester had a weak stimulant effect in lower concentration, but a strong relaxing one in higher concentrations.

10. The effect of GABOB was similar to that of GABA. But, the effects of GABOB and GABOB-methylester were weaker respectively than those of GABA and GABA-methylester. OH-group at $\beta$-position reduced the activity of GABA. 11. Nicotinic acid, isonicotinic acid and their methylesters produced a slight relaxation.

12. The rabbit ileum responded to above mentioned GABA-derivatives with similar manners, but with less sensitivity than the guinea-pig ileum.

13. The cat ileum reacted to these substances with almost the same manners and sensitivity as the guinea-pig ileum.

14. The relation between the structure and the effects of GABA was discussed. 


\section{REFERENCES}

1) Job, C., Schaumann, O. und Schmidt, H. (1955) Die Wirkung der Anoxie auf den isolierten Meerschweinchendarm. Arch. Exper. Path. u. Pharmakol. 226: 130-139.

2) HobBiger, F. (1958). Effects of $\gamma$-aminobutyric acid on the isolated mammalian ileum. J. Physiol. 142: 147-164.

3) HobigGer, F. (1958). Antagonism by $\gamma$-aminobutyric acid to the actions of 5-hydroxytryptamine and nicotine on isolated organs. J. Physiol. 144: 349-360.

4) Inouye, A., Fukuya, M., Tsuchiya, K. ANd Tsujioka, T. (1960). Studies on the effects of $\gamma$-aminobutyric acid on the isolated guinea-pig ileum. Jap. J. Physiol. 10: 167-182.

5) Takahashi, H., Tiba, M., IINo, M. and Takayasu, T. (1955). The effect of $\gamma$-aminobutyric acid on blood pressure. Jap. J. Physiol. 5: 334-341.

6) Purpura, D. P., Girado, M., ANd Grundfest, H. (1957). Mode of action of aliphatic amino acids on cortical synaptic activity. Proc. Soc. Exper. Biol. Med. 95: 791-796.

7) Takahashi, H., Nagashima, A., Koshino, C. and Takahashi, H. (1959). Effects of $\gamma$-aminobutyric acid (GABA), $r$-aminobutyryl choline (GABA-Ch) and their related substances on the cortical activity. Jap. J. Physiol. 9: 257-265.

8) Edwards, C. AND KuUfFler, S. W. (1959). The blocking effect of $\gamma$-aminobutyric acid (GABA) and the action of related compounds on single nerve cells. J. Neurochem. 4: $19-30$. 